\title{
SIKAP KRISTEN DALAM ARENA POLITIK
}

\section{Ferdinan Samuel Manafe}

\section{PENDAHULUAN}

Situasi politik di Indonesia semakin hari semakin panas menjelang pemilihan Presiden dan legislatif. Banyak kader-kader muda, maupun yang sudah sepuh ingin ikut berkecimpung dalam percaturan politik negara ini. Manusia merupakan mahkluk politik dan sudah menjadi hakekat manusia untuk hidup dalam masyarakat, hanya dalam konteks kependudukan, manusia dapat memperoleh sifat moral yang paling tinggi karena urusan-urusan yang berkenaan dengan seluruh masyarakat akan dibicarakan dan diperdebatkan, demi mewujudkan tindakan-tindakan bagi kebaikan bersama yang akan diambil.

Pada kesempatan ini, penulis akan menguraikan mengenai Apa arti politik? Bagaimana pandangan Alkitab terhadap Politik? Bagaimana sikap orang percaya terhadap politik? Apakah orang Kristen boleh ikut terlibat dalam dunia politik?

\section{Pengertian Politik}

Di dalam perkembangannya, pengertian politik semakin meluas dan tidak mungkin memperoleh makna tunggal. Bahkan kehadirannya dalam khasanah ilmu pengetahuan di bidang ilmu-ilmu sosial telah menimbulkan perbedaan di kalangan ahli-ahli politik. ${ }^{1}$ Miriam Budiarjo misalnya menyatakan bahwa politik sebagai ilmu merupakan ilmu yang masih muda dan baru berkembang pada akhir abad ke-19. ${ }^{2}$ Sementara itu ahi lain, William Ebenstein justru dengan tegas menyatakan yang sebaiknya: it is the oldest science!. ${ }^{3}$ Kata politik ini berasal dari bahasa Yunani yaitu polis dan teta. Arti dari kata polis sendiri yaitu kota/negara sedangkan untuk kata teta memiliki arti urusan. ${ }^{4}$ Menurut Wikipedia Ensiklopedia Bebas menyatakan hal tentang politik sebagai berikut:

\footnotetext{
1 Saut Sirait, Politik Kristen di Indonesia Suatu Tinjauan Etis, (Jakarta: BPK.Gunung Mulia, 2011), 19

2 Miriam Budiarjo, Dasar-dasar Ilmu Politik, (Jakarta: Gramedia, 1989), 1

3 William Ebenstein, "Political Science", dalam Encyclopedia Americana, (New York: Americana Corporation, 1972), 309

"Pengertian Makna Dan Definisi Politik Secara Umum Serta Para Ahli", http://www.ikerenki.com/2014/01/pengertian-politik-makna-definisiumum.html, Diakses: 12 Agustus 2016
} 
"Politik berasal dari bahasa Belanda politiek dan bahasa Inggris politics, yang masing-masing bersumber dari bahasa Yunani ta то入ітіка́ (politika -yang berhubungan dengan negara) dengan akar katanya moגítns (polites - warga negara) dan móגıs (polis negara kota). Secara etimologi kata "politik" masih berhubungan dengan polisi, kebijakan. Kata "politis" berarti hal-hal yang berhubungan dengan politik. Kata "politisi" berarti orang-orang yang menekuni hal politik." ${ }^{5}$

Ebenstein menulis, Dilihat dari sisi etimologisnya, kata 'politik' berasal dari kata Yunani, yaitu Polis yang diartikan sebagai kota (city). Dalam perkembangan berikutnya, kota-kota memperluas diri atau menyatukan diri dan kemudian disebut negara. Sebagai ilmu, politik merupakan analisa tentang pemerintahan, proses-proses di dalamnya, bentuk-bentuk organisasi, lembaga-lembaga dan tujuannya ${ }^{6}$ Menurut Hans Kelsen, politik mempunyai dua arti, yaitu politik sebagai etik, yakni berkenaan dengan tujuan manusia atau individu agar tetap hidup secara sempurna. Dan politik sebagai teknik, yakni berkenaan dengan cara (teknik) manusia atau individu untuk mencapai tujuan. ${ }^{7}$ Politik ialah usaha-usaha yang ditempuh warganegara untuk membicarakan dan mewujudkan kebaikan bersama. Seperti yang dikemukakan Aristoteles dan dikutip oleh Yosef Keladu Koten, pandangan klasik melihat politik sebagai suatu asosiasi warganegara yang berfungsi membicarakan dan menyelenggarakan hal ihwal yang menyangkut kebaikan bersama seluruh anggota masyarakat. Hal yang sama juga dinyatakan oleh Sabam Sirait bahwa, "Politik pada dasarnya dan pada awalnya diadakan sebagai keseluruhan tindakan untuk menyempurnakan kebahagiaan kehidupan masyarakat. ${ }^{8}$

Oleh karena itu secara garis besar definisi atau makna dari politik ini adalah sebuah perilaku atau kegiatan-kegiatan yang dilakukan untuk mewujudkan kebijakan-kebijakan dalam tatanan negara agar dapat merealisasikan cita-cita negara sesungguhnya, sehingga mampu membangun dan membentuk negara sesuai aturan

\footnotetext{
${ }^{5}$ Wikipedia, "Politik", https://id.wikipedia.org/wiki/Politik, Diakses 10 Agustus 2017

6 William Ebenstein, Political Science..., 309

"Pengertian Makna Dan Definisi Politik Secara Umum Serta

Para Ahli", http://www.ikerenki.com/2014/01/pengertian-politik-makna-definisiumum.html, Diakses: 12 Agustus 2016

8 Yosef Keladu Koen, Partisipasi Politik: Sebuah Analisis Atas Etika Politik Aristoteles, (Maumere: Penerbit Ledalero, 2010), 75
} 
agar kebahagiaan bersama di dalam masyarakat di sebuah negara tersebut lebih mudah tercapai.

Dari pengertiannya, ada bermacam-macam definisi tentang politik, namun menurut penulis, yang paling cocok adalah "usaha bersama dalam mengambil kebijakan untuk mewujudkan kebaikan bersama".

\section{Misi Kristen Dalam Dunia Politik}

Pada masa ini, politik dikenal dan dimaknai sebagai celaan daripada tindakan luhur. Politik dirasakan dan disaksikan sebagai arena da nasal muasal kericuhan yang terjadi di mana-mana. Sebagian politisi dinilai tamak, licik, munafik dan memiliki prinsip individualis dan sangat egois. Politik itu kotor, penuh aksi maniulatif dan retorika kosong.Citra seperti itulah yang mewarnai atmosfir perpolitikan di negara ini. ${ }^{9}$ Dalam buku Politik Itu Suci, Sabam Sirait menyatakan,

Tak perlu berbagai survei untuk mengkonfirmasi hal tersebut. Simaklah pembicaraan rakyat di warung kopi sampai café, arisan ibu-ibu rumah tangga sampai aksi jalanan mahasiswa, demonstrasi buruh hingga seminar ilmiah para akademisi: bisadipastikan, bila berkaitan dengan urusan politik, yang terdengar adalah sinisme-yang seringkali bernada sarkasme. Hari-hari ini hamper tak terdengar orang membicarakan poitik dengan kalimat positif. ${ }^{10}$

Robertus Robert dan Ronny Agustinus menyatakan, "Politik dimengerti sebagai perilaku buruk kolektif yang secara hukum terlembagakan dan termaklumkan." 11

Dengan kondisi yang buruk dan diangap busuk, politik pada saat yang sama terus diharapkan dan semakin luas dipraktekkan dalam kehidupan sehari-hari. Hal ini memperlihatkan paradoks yang memperlihatkan seakan-akan politik memiliki dua wajah. Di satu sisi, politik terjadi begitu saja dalam rutinitas kelembagaan dan perilaku akor-aktornya yang busuk dan tercela dan di sisi lain, politik diharapkan

9 Imran Hasibuan (ed.), Politik Itu Suci Pemikiran dan Praktik Politik Sabam Sirait, (Jakarta: Gramedia,2013), 1

10 Ibid.

11 Robertus Robert dan Ronny Agustinus (eds.), Kembalinya Politik: Pemikiran Poliik Kontemporer Dalam Imran Hasibuan (ed.), Politik Itu Suci Pemikiran dan Praktik Politik Sabam Sirait, (Jakarta: Gramedia,2013), 2 
namun tidak teraktualisasi dalam kesehariannya. ${ }^{12}$ Kenyataan ini membuat dilema dalam kehidupan kekristenan. Ada sebagian orang yang menyatakan bahwa politik itu kotor. Cukup banyak orang Kristen, termasuk mahasiswa Kristen, yang takut atau antipati terhadap politik. Hal ini terjadi akibat image negatif dari politik yang dianggap tempat iblis atau dosa.Tak jarangpraktek politik di Indonesia, terkadang menggunaan lembaga kegerejaan dalam rangka memuluskan maksud politik seseorang atau partai tertentu. ${ }^{13}$

Kenyataan menuntut, mau tidak mau masyarakat, khususnya umat Kristen, pasti dihadapkan dengan masalah politik dan hukum. Semakin banyak peran dan pengaruh gereja dalam politik dan hukum diharapkan semakin menunjukkan citra Kristus yang ada dalam setiap jemaat-Nya. Pertanyaan kuncinya jelas: apa kata Alkitab terhadap politik? Dalam Alkitab banyak sekali contoh yang tersedia guna dipakai untuk diterapkan dalam kehidupan berpolitik.

\section{Poltik Dalam Perjanjian Lama}

Dalam Alkitab ada begitu banyak contoh tokoh-tokoh Alkitab yang hidup dalam dunia politik, seperti Saul, Daud, Salomo, Daniel, Ester, Mordekhai, dan lain-lain. Melihat kehidupan Saul, maka kita dapat mengambil pelajaran tentang politik kotor yang telah dilakukannya. Saul membenci Daud, dan menganggapnya sebagai lawan yang harus disingkirkan. Saul juga bersikap sombong dan menganggap dirinya mampu sehingga tidak mengandalkan nasehat dan firman Tuhan.Tetapi Daud melakukan apa yang baik, jujur dan berkenan kepada Tuhan. Integritas pribadi yang mulia, ditunjukkan oleh berbagai tokoh dalam Alkitab, bagaimana mereka tetap memegang teguh prinsip kebenaran meskipun nyawa harus menjadi taruhannya.

Jika dilihat dari asal katanya, maka Istilah politik (city) muncul dengan tegas dalam Yeremia(29:7): And seek the peace ofthe city ...and pray to the Lord for it (city: ditambahkan); for in its (city: ditambahkan) peace you will have peace. Dalam Alkitab yang diterjemahkan oleh LAI diartikan mencari atau mengupayakan kesejahteraan kota (politik), jelas merupakan amanat Alkitab pada umat Tuhan. Dengan demikian, penataan politik tidak bisa dilepaskan dari urusan Tuhan di segala tempat, ruang dan waktu.Amanat atau

12 Imran Hasibuan (ed.), Politik Itu Suci Pemikiran dan Praktik Politik Sabam Sirait, (Jakarta: Gramedia,2013), 1

13 Ricko Rasu, "Politik Dalam Kajian Etika Kristen" (Bolehkah Orang Kristen atau Pendeta Berpolitik?), https://plus.google.com/100518052552265367347/posts/SetZpRoy88k, 
perintah Alkitab untuk berpolitik bagi umat di dalam kitab Yeremia itu, tidak serta merta diikuti dengan suatu bentuk atau sistem, apalagi yang menyangkut prosedur dan mekanisme penataan politik yang detail. Tidak ada suatu rumusan politik yang tercantum dalam Alkitab, tetapi menjadi suatu keharusan yang dirumuskan umat Tuhan. Alkitab hanya memberikan suatu konsep yang sangatmendasar: to seek peace (mengupayakan kesejahteraan politik). Kepada umat Tuhan, Alkitab memberikan kesempatan yang seluas-luasnya untuk merumuskan suatu formula politik, baik itu menyangkut dasar dan sistem politik, bentuk, prosedurdan mekanisme pemerintahan. Alkitab hanya memberi satu tekanan dan kepastian:kesejahteraan.

\section{Politik Dalam Perjanjian Baru}

Mengenai politik dalam Perjanjian Baru, penulis akan menguraikannya dengan melihat bagaimana sikap Tuhan Yesus dan Rasul Paulus terhadap politik. Pada zaman Yesus ada empat partai politik yang juga merupakan mazhab dalam agama Yahudi.Jadi, Yesus mempunyai sedikitnya empat pilihan.

Partai Eseni/Kaum Eseni; Sebagaimana kelompok-kelompok Yahudi lainnya, muncul sebagai respon terhadap konflik-konflik yang muncul, di mana identitas Yahudi sedang terancam oleh Helenisasi yang dilancarkan oleh penjajah Romawi. ${ }^{14}$ Kaum Esensi memiliki peertentangan yang kuat terhadapkelompok Farisi dan Saduki, di mana kelompok Farisi dianggap oleh mereka kurang mengikuti hukum Taurat secara literer, sedangkan kaum Saduki dianggap sebagai pemimpinpemimpin agama yang korup dan salah mengerti hukum Tuhan dalam menjalankan kultus Bait Suci. ${ }^{15}$

Partai Sikari atau Zelot; Di dalam Alkitab, beberapa kali disebut mengenai keberadaan orang-orang Zelot.Di dalam daftar murid-murid Yesus terdapat nama Simon orang Zelot (Lukas 6:14-15, Markus 3:18, Matius 10:4), sehinggatampaknya di antara murid Yesus terdapat anggota gerakan Zelot. Selain itu, di dalam perkataan Gamaliel (Kisah Para Rasul 5:36-37) disebut juga dua nama pemimpin pemberontakan, yaitu Teudas dan Yudas. ${ }^{16}$

Partai Saduki; Kata Saduki atau saddoukaios (baca: Saddoukaios), dalam bahasa Inggris diterjemahkan Sadducees yang

14 John Stambaugh, David Balch, Dunia Sosial Kekristenan Mula-Mula, (Jakarta: BPK GunungMulia, 1997), 122.

15 John Stambaugh, David Balch, Dunia Sosial Kekristenan Mula-Mula, (Jakarta: BPK Gunung Mulia, 1997), 122.

16 Bart D. Ehrman, The New Testament: A Historical Introduction... 
artinya "the righteous" atau orang benar. ${ }^{17}$ Saduki adalah salah satu partai agama pada zaman Kristus di antara orang Yahudi, yang menyangkal atau menolak penyataan lisan adalah suatu Wahyu Tuhan yang diberikan Tuhan kepada bangsa Israel, dan yang dianggap hukum tertulis saja untuk menjadi wajib pada bangsa, sebagai otoritas yang ilahi. Mereka menolak doktrin-doktrin berikut: kebangkitan tubuh, kekekalan jiwa, adanya roh dan malaikat, penentuan ilahi, meneguhkan kehendak bebas. $^{18}$

Saduki adalah nama dari kelompok aristokratik Yahudi yang berkuasa di Yerusalem hingga Bait Suci dihancurkan pada tahun 70 M. ${ }^{19}$ Kaum Saduki juga bertanggung jawab terhadap ibadah yang dilakukan di Bait Suci sebagai kaum imam, di mana hampir seluruh imam-imam dapat digolongkan sebagai kaum ini. ${ }^{20}$ Jabatan Imam Besar Yahudi pada umumnya diduduki oleh orang Saduki, tetapi tidak semua orang Saduki adalah imam. ${ }^{21}$ Ada kemungkinan bahwa orangorang Saduki juga terdiri dari orang awam yang kaya dan tuan-tuan tanah. ${ }^{22}$

Partai Farisi; Kaum Farisi adalah pemimpin spiritual Yahudi yang berkembang padamasa Bait Allah ke-2, sekitar abad ke 2 SM. Menurut para ahli, kaum Farisi adalah perkembangan dari kelompok Hasidim. Kelompok Hasidim adalah kelompok yang menganggap diri mereka sebagai orang beragama yang saleh.Kelompok Hasidim memisahkandiri dari orang biasa. ${ }^{23}$

Yesus tidak menjadi anggota salah satu partai itu. Akan tetapi, Yesus berpolitik dalam pengertian la mempunyai sikap politik. Sikap politik-Nya antara lain tampak ketika orang bertanya apakah pantas membayar pajak kepada pemerintah penjajah. Yesus menjawab, "Berikanlah kepada kaisar apa yang wajib kamu berikan kepada Allah" (Mat.22:21). Sepintas lalu jawaban Yesus ini terkesan menyangkut urusan pajak, namun sebetulnya jawab itu mengandung sebuah isu yang bersifat mendasar, yaitu tentang hubungan agama dan

17 Strongs \#4523 James Strong, The New Strong's: Exhaustive Concorcordance Of The Bible, (Nashville- Tennessee: Nelson's, 1990)

18 Strongs \#4523 a religious party at the time of Christ among the Jews, who denied that the orallaw was a evelation of God to the Israelites, and who deemed the written law alone to be obligatory onthe nation, as the divine authority. They denied the following doctrines: resurrection of the body; immortality ofthe soul, existence of spirits and angels; divine predestination, affirmed free will

19 Bart D. Ehrman, The New Testament: A Historical Introduction...

20 Ibid.

21 S. Wismoady Wahono.1986. Di Sini Kutemukan. \{Jakarta:: BPK Gunung Mulia,1986), 325-326

22 Ibid.

23 George Foot More, Judaism. (USA: Hendrickson Publisher, 1960),59. 
negara.Dalam jawaban itu Yesus menunjukkan bahwa setiap orang mempunyai dua kewajiban atau dua tanggung jawab, yaitu "Apa yang wajib kamu berikan kepada kaisar?" dan "Apa yang wajib kamu berikan kepada Allah". Dengan kata lain, setiap orang mempunyai dua kewarganegaraan, sebagaikuasa di Yerusalem hingga Bait Suci dihancurkan pada tahun $70 \mathrm{M}$. Kaum Saduki juga bertanggung jawab terhadap ibadah yang dilakukan di Bait Suci sebagai kaum imam, di mana hampir seluruh imam-imam dapat digolongkan sebagai kaum iniwarga negara Kerajaan Roma dan sebagai warga negara Kerajaan Allah. Selanjutnya, jawaban Yesus itu berimplikasi bahwa negara dan agama merupakan dua hal yang berbeda.Negara dan agama mempunyai bidang, urusan, tugas, dan wewenangnya masingmasing.Tidak boleh negara dan agama dicampur menjadi satu.Saut Sirait menulis, Politik teokrasi dinyatakan Yesus secara implisit, sebab dengan sengaja Yesus memberikan garis tegas yang membedakan Allah dan kaisar. Kesatuan ilahi di dalam totalitas kosmologi otokrasi ${ }^{24}$ jelas ditolak dengan pemisahan yang jelas antara Allah dan kaisar. ${ }^{25}$ Mengenai teks Matius 22:21 ini, Barclay menyatakan bahwa, "Dengan hikmat-Nya yang unik, Yesus tidak menetapkan hukum dan peraturan. Itulah ajaran-Nya tidak dibatasi oleh waktu dan tidak pernah usang...Di sini la memberikan sebuah prinsip yang sangat penting dan sangat luar biasa." ${ }^{\text {26 }}$ Sikap politik Yesus yang lain tampak dalam pernyataan-Nya, "Kamu adalah garam dunia...kamu adalah terang dunia" (Mat.5:13-14). Jangankan menjauh dari dunia, Yesus malah menyuruh pengikut-Nya menjadi orang yang menggarami (artinya: menjadi pencegah kebusukan) dan menerangi (artinya:menjadi hati nurani) dunia.

\section{Sikap Rasul Paulus Terhadap Politik}

Pemaparan mengenai proses masuknya Injil Kristus ke jantung Imperium Romawi merupakan salah satu faktor penting untuk memahami konsep politik Perjanjian Baru. Dan teks firman Tuhan yang paling sering mendapat perhatian mengenai politik adalah tulisan Rasul Paulus dalam Roma 13:1-7 ${ }^{27}$. Roma 13:1-7 menjelaskan bagaimana

24 Otokrasi adalah suatu bentuk pemerintahan yang kekuasaan politiknya dipegang oleh satuorang. Istilah ini diturunkan dari bahasa Yunani autokratôr yang secara harfiah berarti "berkuasasendiri" atau "penguasa tunggal". https://id.wikipedia.org/wiki/Otokrasi

25 Saut Sirait, Politik Kristen di Indonesia: Suatu Tinjauan Etis, (Jakarta: BPK.Gunung Mulia,2011), 117-118

26 William Barclay, Pemahaman Alkitab Setiap Hari: Injil Matius Pasal 11 -28, (Jakarta: BPK.Gunung Mulia, 2015), 433

27 Saut Sirait, Politik Kristen di Indonesia: Suatu Tinjauan Etis, (Jakarta: BPK.Gunung Mulia,2011), 123 
hidup sebagai warga negara yang dipimpin oleh pemerintah. Jemaat Kristen yang ada di Roma diingatkan oleh Rasul Paulus untuk taat dan setia kepada pemerintah. Paulus adalah Keturunan Yahudi asli dan sejak kecil sudah menjadi warga negara Romawi.Paulus sangat terbuka terhadap realitas di luar keyahudiannya, baik terhadap Yunani maupun Romawi. ${ }^{28}$ Namun dalam teks ini,tertuang legitimasi teologis yang kuat yang diberikan Paulus kepada pemerintah. Hal ini oleh Sirait dijelaskan bahwa, pernyataan: "tiap-tiap orang harus takluk" (pasa psuke), yang arti harfiahnya "setiap jiwa berlaku umum; yaitu untuk orang Kristen dan non Kristen.. Sedangkan kata "takluk" diambil dari kata kerja hupotassesthai yang artinya "menempatkan diri di bawah". ${ }^{29}$ Dengan demikian, sikap takluk merupakan bentuk aktif yang berangkat dari diri sendiri.Takluk itu berdasarkan pilihan sadar seseorang, bukan sesuatu yang dipaksakan dari luar dirinya. Hal ini diperkuat pada ayat 5 yang dengan eksplisit menyebutkan pemakaian hati nurani. Jadi makna yang dapat diambil adalah, orang Kristen harus memiliki kesadaran bahwa dirinya memiliki kewajiban dan tanggung jawab terhadap pemerintah. Walaupun sudah diselamatkan oleh Kristus, bukan berarti orang Kristen berada $d$ atas atau di luar hukum dan di atas penguasa-penguasa.

Sebagai orang beriman mestinya percaya bahwa pemerintah suatu negara dipakai Allah sebagai wakil-Nya di dunia untuk menata kehidupan masyarakat. Hal ini sesuai dengan apa yang telah dijelaskan dan diterangkan oleh penulis surat Roma 13:1-7. Oleh sebab itu dikatakan bahwa kepedulian terhadap kehidupan bersama negarawi merupakan tanggung jawab yang tidak dapat diabaikan oleh orang Kristen/gereja. ${ }^{30}$ Di dalam 1 Timotius 2:1-2, ada himbauan Paulus kepada Timotius untuk mendukung para pemimpin demi hidup tenang dan tentram. Paulus juga menggunakan istilah polis dalam Alkitab dihubungkan dengan status politik seseorang. Contohnya: Bendahara kota (Roma 16:23); hak Paulus sebagai warga kota (Kisah Para Rasul 21:39); warga Negara (Filipi 3:20); hak warga Israel (Efesus 2:12).

Maka beberapa pandangan di atas dapat memberikan masukkan tentang bagaimana memahami politik dan bersikap terhadapnya. Dan ketika dihubungkan antara kesejahtraan sebuah kota atau negara dengan pemerintah, maka didapatilah sebuah korelasi bahwa demi mencapai sebuah usaha atau pemikiran dalam mensejahtrakan kota atau negara dibutuhkan kekuasaan, struktur kekuasaan, kebijakkan kekuasaan, bahkan ilmu kekuasaan.

28 Band. Ibid., 123-130

29 Ibid.

30 Solarso Sopater (peny.), Seri Membangun Bangsa: Keadilan dalam Kemajemukan. (.Jakarta:Pustaka Sinar Harapan, 1998), 49. 


\section{Implikasi Politik Bagi Orang Percaya}

Bagaimana sikap orang percaya terhadap politik?Apakah orang Kristen boleh ikut terlibat dalam dunia politik? Dari fakta sejarah, ada keterlibatan beberapa tokoh yang beragama Kristen dalam ranah politik seperti, Desmond Mpilo Tutu, Martin Luther King, Jr., Elisabeth Fry, William Wilberforce, John Calvin, yang mengubah dunia dan telah meninggalkan sejarah perjuangan atas ketidakadilan dan kebenaran, yang sangat mengagumkan. ${ }^{31} \mathrm{Hal}$ ini memperlihatkan bahwa Allah mengijinkanketerlibatan orang percaya dalam dunia politik.Pelajaran pentingnya adalah bahwa kekristenan jangan alergi terhadap politik.Beberapa alasan adalah politik dari segi normative merupakan hal yang mulia. Dalam pengertian bahwa keadilan dan kebenaran menjadi tujuan politik harus mendapat tempat dihati orang Kristen untuk diperjuangkan tanpa mengenal lelah.Kemudian keterlibatan dalam dunia politik telah diawali dengan sebuah panggilan perjuangan atas ketimpangan atau persoalan sosial sebagai motivasi. Dan dunia politikmerupakan sarana mencapai tujuan itu. Orang Kristen bahkan pelayan khusus dapat mengambil bagian dalam dunia politik sebagai keterpanggilannya atas dunia dan menebarkan terang di dalam Kristus sebagai patokan etis dalam menangani masalah dunia, asalkan ia tetap dalam memperjuangkan hak normatif sebagai motivasi murninya dan meninggalkan politik praktis yang berpusat kepada kekuasaan dengan menggunakan segala cara untuk mencapai tujuan.

\section{a. Gereja}

Dalam dunia politik dan hukum, sikap gereja yang perlu dkembangkan adalahsikap positif, kritis, dan kreatif. Positif artinya memandang dunia politik dan hukum sebagai bidang pengabdian dan pelayanan panggilan dari Tuhan karena itu berasal dari pandangan positif ketika memberikan kontribusi sesuai iman Kristen.Kritis artinya tidak ragu-ragu memberi kritik jika penguasa berbuat kesalahan, menyimpang dari hukum dan prinsip-prinsip yang berlaku.Kritik yang sesuai dengan etika Kristen adalah kritik yang konstruktif (membangun, santun, dan memperdayakan), bukan kritik yang destruktif (menjatuhkan, vulgar, dan mencari kesalahan). "Gereja bersama dengan lembaga-lembaga keagamaan lain tidak boleh meyerahkan moralitas politik kepada elit politik saja. Yang dibutuhkan adalah moral politik yang benar-benar menjaga harkat dan martabat

${ }^{31}$ Ricko Rasu, "Politik Dalam Kajian Etika Kristen" (Bolehkah Orang kristen atau PendetaBerpolitik?), Https://plus.google.com/100518052552265367347/posts/SetZpRoy88k, Diakses 10Agustus 2017 
manusia.Keterlibatan gereja dalam politik adalahuntuk menegakkan dimensi moral dalam poitik. Politik tanpa moral yang baik akan selalu menghasilkan penyalahgunaan kekuasaan untuk menindas sesama manusia. Gereja harus menjadi penjaga yang efektif dalam dunia politik agar hargamanusia tidak direduksi dan didistorsi”.32 Gereja harus kreatif, maksudnya gereja perlu berusaha memberikan terobosan atau alternatif baru di tengah kebuntuan terhadap politik maupun hukum. Gereja diharapkan mampu berkomunikasi terbuka dan dialogis, tidak alergi terhadap perubahan. Selain itu, gereja juga dapat memberikan kontribusi yang signifikan dalam bidang politik dan hukum antara lain: Gereja perlu terlibat dalam politik dan hukum dalam arti yang luas, gereja mengikuti dengan berbagai perkembangan politik dan hukum. Gereja perlu melakukan pertemuan yang bersifat konsultatif secara berkala dengan anggota-anggota jemaatnya yang terlibat dalam politik dan hukum praktis dan terlibat dalam forum-forum dialog antar umat beragama.

\section{b. Orang Percaya}

Sikap orang Kristen terhadap politik ada 3 yaitu, bersifat antagonistis,rejektif, dan menyesuaikan. Respon yang benar itulah yang lebih penting dan menentukan sikap orang percaya terhadap berbagai gejolak politik yang terjadi.Allah menghendaki orang Kristen taat kepada pemerintah, sesuai dengan pengertian bahwa pemerintah menjalankan tugas dan wewenang yang diberikan oleh Allah. Pemerintah harus mempertanggungjawabkannya kepada pemberi kekuasaan yaitu Allah sendiri (ayat 1). Jika orang Kristen tidak taat kepada pemerintah dan berpartisipasi secara aktif sebagai warga negara yang bertanggung jawab maka citra keKristenan akan rusak.

Orang Kristen harus menghormati kewibawaan pemerintahan dunia selama kebijakan itu dilakukan demi kesejahteraan masyarakat dan didasarkan pada undang-undang yang berlaku. Tetapi kebijakan itu tidak boleh mengambil alih kewibawaan atau wewenang Allah. Bagaimana seharusnya orang Kristen sebagai warga negara menaati lembaga-lembaga resmi negara yang mengatur kehidupan masyarakat dalam usahanya menegakkan kebenaran dan keadilan kesejahteraan masyarakatditulis di Roma 13:13. Orang Kristen harus mengakui lembaga pemerintahan yang diadakan oleh karena kehendak Allah (ayat 1). Panggilan tersebut tentu menuntut peran aktif, yang harus dimulai dari pasal 12, yaitu penyerahan diri kepada Allah (Roma

32 Th. Sumartana, "Panggilan Gereja dalam Reformasi Politik di Indonesia: Sebuah Refleksi.Dalam buku Struggling in Hope, (Jakarta; BPK. Gunung Mulia, 2002), 208 
12:1, 2) sehingga tidak menjadi serupa dengan dunia. Dengan demikian pemerintah dapat berperan sebagai hamba Allah (Roma 13:4). Ayat 5,"... dengan suara hati” Justru di sinilah tugas dan tanggung jawab gereja (dalam pengertian umat Allah, bukan dalam pengertian organisasi) supaya memampukan pemerintah menjadi hamba Allah. Hal ini dapat terjadi hanya apabila orang Kristen memenuhi panggilannya. Jadi sudah seharusnya orang percaya menjawab panggilan itu, untuk menjadi garam dan terang dunia, biar melalui diri orang percaya, citra Kristus boleh terpancar sehingga semua orang memuji dan memuliakan Allah.

\section{c. Sikap terhadap Pemerintah yang Salah Menggunakan Otoritas}

Berkaitan denganpemerintah (kepatuhan kepada pemerintah), Roma 13:1-7 menyatakan bahwa pemerintah adalah hamba Allah. Kekuasaan pemerintah berasal dari Allah, oleh karena itu pemerintah wajib menjalankan kehendak Allah untuk mengupayakan keamanan dan kesejahteraan rakyat. Maka titik tolak pelaksanaan tugas-tugas pemerintah (hukum atau undang-undang) haruslah bersesuaian dengan kehendak Allah. Sehubungan dengan itu, pemerintah berhak dan wajib menjalankan hukuman kepada orang yang bersalah. Sebagai umat yang telah mengenal kebenaran di dalam Kristus, tentunya setiap orang percaya bisa menilai apakah sesuatu itu benar atau tidak. Kematian Kristus adalah untuk menghancurkan kerajaaan kegelapan dan menegakkan Kerajaan Allah, dan orang Kristen dipanggil untuk menyatakan kehendak Allah dan memuliakan nama-Nya dalam segala bidang kehidupan.Kecintaan kepada bangsa itu tidak boleh dipisahkan dengan kecintaan Tuhan Allah. Oleh sebab itu, orang Kristen mempunyai kewajiban yang lebih berat dalam perkara politik daripada orang lain. Sebab di bidang politik dan pemerintahan, peran orang Kristen bukan semata-mata demi kesejahteraan bangsa, tetapi yang terutama semuanya dilakukan untuk kemuliaan nama Tuhan. Pemimpin yang berkuasa ditunjuk oleh Tuhan tercatat dalam surat Rasul Paulus kepada jemaat di Roma, "tiap-tiap orang harus takluk kepada pemerintah yang di atasnya" (Roma 13:1). Frasa setiap orang menyatakan tidak ada pengecualian. Sebagai orang Kristen tidak boleh menentang pemimpin yang sah..Sebab tidak ada pemerintah yang tidak ditetapkan oleh Allah. Pada zaman ini, para pemegang kekuasaan memiliki reputasi negatif. Banyak pemimpin, salah menggunakan otoritas yang dimiliki. Tidak heran rasa hormat terhadap pemimpin negara tampak seperti kebodohan.. Namun,Tuhan mengatakan harus menghormati pemimpin atau penguasa yang sah, tidak peduli bagaimanapun kepemimpinannya karena secara tegas 
dinyatakan bahwa semua otoritas berasal dari Tuhan atau ditetapkan Allah. Banyak orang yang benar-benar bergumul dengan arti dari ayat ini, perintah ini bisa tampak sangat tinggi untuk mungkin ditaati oleh setiap orang Kristen. Tetapi itulah tantangan untuk menjadi seorang pengikut Kristus.

\section{Implikasi}

Sikap orang Kristen dalam kehidupan politik hendaknya didasari atas pemahaman bahwa : Berpolitik dalam hal ini sebagai anugerah Allah. Berpolitik bukan sesuatu yang buruk. Dengan demikian, jabatan dan kekuasaan itu dipandang sebagai kesempatan untuk mengabdi kepada Tuhan melalui pelayanan kepada rakyat. Keberpihakan kepada yang lemah. Para politikus Kristen dipanggil karena memiliki keberpihakkan kepada yang lemah, karena dua alasan penting yaitu kelompok masyarakat inilah yang sering kali menjadi korban penindasan, ketidakadilan dan kesewenang-wenangan. Keberpihakan mereka tidak boleh dilandasi oleh sentimen yang bersifat primodial (suku, ras, atau agama). Namun, keberpihakan itu juga tidak membuat aturan dan hukum tidak berlaku bagi kelompok ini.

Memiliki visi dan misi yang berorientasi pada rakyat dan kerajaan Allah. Seorang politisi Kristen wajib memiliki karakter yang kuat. Karakter itu tercermin dalam konsistensi sikapnya pada suatu isu tertentu yang menyangkut kepentingan rakyat. Menurut Hasibua, ada tiga aspek kepribadian yang saling menunjang yang perlu dimiliki oleh para pemimpin (dalam hal ini berlaku juga untuk para politisi Kristen) yaitu vision, values, courages (visi, nilai-nilai moral dan keberanian). Yang terutama dari ketiga aspek kepribadian ini adalah visi. Karena dengan visi yang jelas (shared vision), penjabaran konsep dan sasaran organisasi akan dapat dikembangkan. ${ }^{33}$

Visi dan misi para politikus Kristen hendaknya tidak hanya dibatasi oleh lingkup dan waktu. Maksudnya kiprah dalam dunia politik tidak hanya dibatasi oleh konstituennya saja (kelompok pemilihnya) ataupun jangka waktu memiliki jabatan itu. Bahkan lebih jauh lagi para politikus Kristen juga sekaligus adalah agen-agen eskatologis dan seharusnya ikut serta dalam menghadirkan tanda-tanda Kerajaan Allah (keadilan, kebenaran, perdamaian dan keutuhan ciptaan) sampai dengan sepenuhnya.

Mendorong perubahan yang benar dalam masyarakat Indonesia. Para politikus Kristen hendaknya juga menjadi agen-agen

33 Imran Hasibuan (ed.), Politik Itu Suci Pemikiran dan Praktik Politik Sabam Sirait, (Jakarta:Gramedia,2013), 43 
perubahan.Untuk itu dibutuhkan keteladanan sikap perilaku yang baik. Setiap politikus Kristen harus berani mengatakan "tidak" atas semua tawaran, bujukan, atau strategi-strategi yang dapat membuat jatuh pada tindak korupsi, kolusi ataupun nepotisme; menjauhi segala bentuk premanisme dan menegakkan hukum secara konsisten dan konsekuen.

\section{SIMPULAN}

Manusia diberi kuasa atas ciptaan. Allah berfirman kepada manusia pertama: "Penuhilah bumi dan taklukanlah itu, berkuasalah atas ikan-ikan di laut dan burung-burung di udara dan atas segala binatang yang merayap di bumi" (Kej.1:28). Kuasa menjadi sebagian struktur ciptaan. Allah melihatnya, "sungguh amat baik" (Kej.1:31). Manusia, seperti seluruh ciptaan, hidup di bawah kuasa Allah.Tetapi manusia, berbeda dengan ciptaan lain, juga diberi kuasa sebagai subyek.la berkuasa atas makhluk yang lain. Pelaksanaan kuasa manusia atas manusia yang lain juga merupakan sebagian aturan kehidupan yang ditentukan Allah. "Tidak ada pemerintah yang tidak berasal dari Allah" (Roma 13:1). Orang Kristen boleh berpolitik;ia boleh berkuasa. Orang Kristen berpolitik bukan untuk menghapuskan kuasa, tetapi untuk berusaha supaya kuasa dapat dipakai untuk tujuan yang benar dan adil. Orang Kristen perlu belajar bagaimana menghubungkan moralitas dengan kuasa supaya ia berhasil memperbaiki masyarakat.

Sikap politik Yesus itu menjadi dasar bagi keterlibatan gereja dalam politik.Jelas, gereja bukanlah lembaga politik. Gereja tidak menyamakan diri dengan sebuah partai politik. Gereja tidak menganjurkan umatnya memilih partai tertentu. Akan tetapi, gereja melakukan pendidikan politik. Salah satu bidang Pendidikan Agama Kristen (PAK) Orang Dewasa adalah pendidikan politik melalui khotbah, buku, pemahaman Alkitab, dan yang lainnya. Itu bukan berarti bahwa kita menjadi anggota suatu partai, melainkan bahwa kita mempunyai kesadaran politik. Kita bukan bersikap masa bodoh, melainkan mengkritisi keadaan dengan cara setiap hari membaca fakta dan opini di surat kabar. Kristus adalah Tuhan atas diri kita sebagai individu dan juga atas diri kitasebagai bangsa dan Negara. Oleh sebab itu, kita turut berpartisipasi dalam menentukan warna keyakinan dan kebijakan mengatur Negara. Salah satu cara partisipasi itu adalah ikut pemilu dan pilkada.

Dengan ikut politik, orang percaya ikut menentukan nasib hari depan masyarakat sebab suara setiap orang percaya yang berhak ikut 
dalam demokrasi politk akan ikut dihitung. Di situlah orang percaya bisa memilih pemimpin yang bersih, gesit, cakap, kreatif, produktif, berintegritas dan dapat dipercaya, serta adil terhadap semua golongan etnik atau agama. Dengan partisipasi itu orang percaya sedang bersikap politis yang alkitabiah. Politik yang alkitabiah adalah suatu upaya dan proses sadar untuk memahami dan memaknai realitas politik dari cara pandang dan pola pikir Alkitab.

Sebagai orang percaya yang mau atau sudah terjun dalam dunia politik agar hidup sesuai kebenaran firman Tuhan. Lakukanlah yang baik dan berkenan kepada Tuhan, bersikaplah jujur dan miliki integritas sebagai orang-orang yang percaya kepada Tuhan Yesus Kristus, berani menanggung resiko dari prinsip kebenaran yang dipegang teguh, dan menolak dosa dan tawaran duniawi.

Berpolitik bukan berarti boleh kompromi dengan dosa atau halhal yang tidak berkenan kepada Allah. Dalam berpolitik semua orang percaya harus mengedepankan prinsip firman Tuhan supaya tidak terjadi hasil keputusan yang bertentangan dengan isi firman Tuhan. Mazmur 37:27 berkata: "Jauhilah yang jahat dan lakukanlah yang baik, maka engkau akan tetap tinggal untuk selama-lamanya." Kalau engkau setia dan taat kepada firman-Nya dan melakukan dengan sungguhsungguh apa yang dikehendaki Tuhan dalam hidupmu, maka engkau akan diangkat Tuhan kepada posisi yang terbaik sehingga nama Tuhan dipermuliakan melalui kehidupanmu. Politik itu bersih di tangan orang yang bersih hati dan sikapnya, tetapi kotor di tangan orang yang jahat. Ingatlah akan penderitaan sesamamu dan lakukanlah yang terbaik untuk kebaikan semua tanpa mengabaikan kebenaran iman Kristiani.

\section{DAFTAR PUSTAKA}

Barclay, William

2015 Pemahaman Alkitab Setiap Hari; Injil Matius Pasal 11 -28. Jakarta: BPK,Gunung Mulia

Budiarjo, Miriam,

1989 Dasar-Dasar IImu Politik. Jakarta: Gramedia

Ebenstein, William,

1972 "Political Science", dalam Encyclopedia Americana. New York: Americana Corporation 
Ehman, Bart D.,

2004 The New Testament: A Historical Introduction to the Early Christian Writings. New York, Oxford: Oxford University Press

Hasibuan, Imran (ed).,

2013 Politik itu Suci Pemikiran dan Praktik Politik itu Sabam SIrait. Jakarta: Gramedia

Koten, Yosef Keladu,

2010 Partisipasi Politik:SebuahAnalisisAtasEtika

Politik Aristoteles. Maumere: Penerbit Ledalero More, George Foot,

1960 Judaism. USA: Hendrickson Publisher

Robert, Robertus dan Ronny Agustinus (eds),

2014 Kembalinya Politik: Pemikiran Politik Kontemporer Dalam Imran Hasibuan (ed), Politik itu SUci Pemikiran dan Praktik Politik Sabam Sirait. Jakarta: Gramedia

Sirait, Saut,

2011 Politik Kristen di Indonesia Suatu Tinjauan Etis. Jakarta: BPK Gunung Mulia

Sopater, Soelarso (peny).,

1998 Seri Membangun Bangsa: Keadilan dalam

Kemajemukan. Jakarta: Pustaka Sinar Harapan

Stambaugh, John, David Balch,

1997 Dunia Sosial Kekristenan Mula-Mula. Jakarta: BPK Gunung Mulia

Strong, James,

1990 The New Strong's: Exhausitive Concordance of The Bible. Nashville,Tennessee: Nelson's

Sumartana, Th.,

2002 "Panggilan Gereja dalam Reformasi Politik di Indonesia; Sebuah Refleksi. "Dalam Buku Struggling in Hope. Jakarta: BPK Gunung Mulia

Wahono, S. Wismoady,

1986 Di Sini Kutemukan. Jakarta: BPK Gunung Mulia 


\section{Sumber Internet:}

Rasu, Ricko,Tt "Politik dalam Kajian Etika Kristen" (Bolehkah Orang Kristen atau Pendeta Berpolitik), internet, Diakses 10 Agustus 2017

Wikipedia "Politik", https://id.wikipedia.org/wiki/Politik, Diakses 10 Agustus 2017 "Otokrasi", https://id.wikipedia.org/wiki/Otokrasi, Diakses 12 Agustus 2017

"Pengertian Makna dan Definisi Politik Secara Umum Serta Para Ahli", http://www.ikerenki.com/2014/pengertian-politik-makna-definisiumum,html, diakses 12 Agustus 2016 